\title{
GESTÃO ESCOLAR MILITARIZADA: UMA ANÁLISE JURÍDICO- ADMINISTRATIVA DO CASO DO TOCANTINS
}

\author{
Mariana Freiria Dallacqua ${ }^{1}$ \\ Aline Sueli de Salles Santos ${ }^{2}$
}

\begin{abstract}
Resumo: A gestão escolar militarizada tem como uma de suas principais justificativas o anseio por disciplina. Atualmente, há 15 escolas estaduais geridas conforme o modelo no Tocantins, das quais 3 surgiram por meio do Programa Nacional das Escolas Cívico-Militares. O estudo pretende verificar se as estruturas normativas e administrativas das escolas estaduais militarizadas do Tocantins atendem os princípios constitucionais e legais da educaçáo básica na qual se inserem. Para isso, propóe-se dissertar sobre o direito educacional, abordar o fenômeno da militarização e verificar a estrutura organizacional das escolas, isto é, como os militares nelas se inserem, além de contrastar as normativas e a estrutura escolar com a Constituição Federal de 1988 e com a Lei de Diretrizes e Bases da Educação Brasileira. A metodologia utilizada é a dialética e a abordagem é qualitativa e de caráter exploratório, já que se vale principalmente da pesquisa documental, bibliográfica e do estudo de caso. Percebe-se que os militares assumem papel de protagonismo no seio escolar, ocupando cargos de coordenação e direção, e que a rigidez e as tradiçôes apresentadas nos quartéis são transplantadas para as instituiçóes, de modo a violar ou restringir, em certas situaçóes, a liberdade de expressão, intimidade e vida privada dos alunos.
\end{abstract}

Palavras-chave: gestão escolar compartilhada; escola cívico-militar; militarização.

\section{MILITARIZED SCHOOL MANAGEMENT: A LEGAL- ADMINISTRATIVE ANALYSIS OF THE TOCANTINS CASE}

\begin{abstract}
The militarized school managment has as one of its main justifications the aspiration for discipline. Currently, there are 15 public schools managed according to Tocantins' style, of which 3 arose from the National Program of Civic-Military Schools. This study aims to verify if the normative and adminstrative structures of the Tocantins' militarized public schools comply with the constitutional and legal principles of the basic education in which they are inserted. Therefore, it is intended to expatiate about the educational law, to address the militarization phenomenon
\end{abstract}

1 Universidade Federal do Tocantins.

2 Doutora em Direito (UnB) e professora adjunta da UFT.

-- Artigo recebido em 08/12/2020. Aceito em 05/05/2021. --

Signos, Lajeado, ano 42, n. 1, p. 9-36, 2021. ISSN 1983-0378 
and to verify the schools organizational structures, that is, how the military insert themselves in them, besides contrasting the normatives and school structure with the Federal Constitution of 1988 and with the Brazilian Education Guidelines and Bases Law. It is used the dialetics methodology and the qualitative and exploratory approach, since it is mainly used documentary, bibliographic and case study research. It is noticed that the military assume a leading role in the school system, occupying positions of coordinators and principals, and that the rigidity and traditions presented in the barracks are transplanted to the institutions, in order to violate or restrict, in certain situations, freedom of speech, intimacy and private life of the students.

Keywords: shared school management; civic-military school; militarization.

\section{INTRODUÇÃO}

A militarização é um traço forte no Brasil e ultrapassa as instituições militares, repercutindo na sociedade civil. Apesar do tratamento constitucional acerca da destinação das Forças Armadas e dos órgãos de segurança pública, estes organismos atuam, em alguns casos, com finalidade diversa da originária. A gestáo escolar militarizada é uma manifestação desse fenômeno. Busca-se, neste trabalho, abordar a gestáo escolar militarizada em escolas estaduais no Tocantins.

Objeto de opiniốes controversas, a partilha com militares da gestão de escolas civis encontra-se em processo de expansão no país, contando com iniciativas locais e federal. A proposta desse trabalho é o estudo das normativas referentes às escolas estaduais militarizadas no Tocantins. A principal contribuição relaciona-se à concretude do objeto e ao cunho jurídico, ainda pouco abordado em estudos similares no âmbito do Estado.

A pergunta norteadora é: as estruturas normativas e administrativas das escolas estaduais militarizadas do Tocantins atendem os princípios constitucionais e legais da educação básica, na qual se inserem? Do ponto de vista da natureza, trata-se de pesquisa aplicada, já que conta com objeto de estudo concreto. Quanto à abordagem, trata-se da qualitativa. Preocupa-se, antes de tudo, em analisar a influência do militarismo no modelo escolar. No que diz respeito aos seus objetivos, trata-se de pesquisa exploratória, pois recorre principalmente às pesquisas documental e bibliográfica e ao estudo de caso.

Por se tratar de um objeto de estudo que deve ser analisado à luz de fatos históricos, sociais e políticos e cuja abordagem é principalmente qualitativa, utilizase a metodologia dialética e os métodos histórico e comparativo.

Nessa conjuntura, pretende-se contribuir com a área do Direito, notadamente constitucional e educacional, a fim de analisar as normativas das escolas militarizadas, de que modo se inserem os agentes militares na estrutura dessas escolas e como tem sido a experiência das escolas objeto dessas parcerias. 


\section{O DIREITO À EDUCAÇÃO BÁSICA E O PROCESSO DE MILITARIZAÇÁO DAS ESCOLAS}

A educação é direito social fundamental para o alcance dos demais. "Democracia é, literalmente, educação." (TEIXEIRA, 2002, p.35). Este capítulo aborda a educaçáo enquanto direito, os princípios que a norteiam, a competência dos entes federados para a sua oferta e, em ato contínuo, o contexto no qual se deu a expansão do modelo escolar militarizado no país.

\subsection{O Direito à Educação Básica}

Constituída por três etapas - educação infantil, ensino fundamental e ensino médio -, a educação básica reflete a forma pela qual se organiza a educação escolar nacional, relacionando-se ao pacto federativo e à organização pedagógica das instituiçóes. "[...] é um conceito mais do que inovador para um país que, por séculos, negou, de modo elitista e seletivo, a seus cidadáos, o direito ao conhecimento pela ação sistemática da organização escolar" (CURY, 2008, p. 294).

A educação infantil tem como público-alvo crianças de zero a cinco anos de idade. O fundamental compreende dois ciclos: fundamental I, do $1^{\circ}$ ao $5^{\circ}$ ano, e fundamental II, do $6^{\circ}$ ao $9^{\circ}$ ano. O ensino médio, por sua vez, tem duração de três anos - do $1^{\circ}$ ao $3^{\circ}$ ano.

Ranieri (2013) afirma que o direito à Educação possui peculiaridades que o distingue dos demais direitos fundamentais, ainda que todos tenham natureza jurídica de direitos subjetivos:

É direito fundamental social, é direito individual e também direito difuso e coletivo, de concepção regida pelo conceito de dignidade humana. É igualmente dever fundamental. Os seus titulares e os seus sujeitos passivos são, simultaneamente, uma coisa e outra. Comporta obrigaçóes de fazer e não fazer, por parte de titulares e sujeitos passivos, que não se exaurem e exigem diferentes atendimentos, algumas vezes sob a reserva do possível. Seu regime jurídico, portanto, é complexo: envolve diferentes poderes e capacidades de exercício, com a inerente sujeição ao regime jurídico específico dos direitos fundamentais mesmo dependendo de prestaçóes materiais e de recursos financeiros. (RANIERI, 2013, p. 55).

Dadas as suas peculiaridades, alguns pontos devem ser ponderados. Há dispositivos tanto na Constituição Federal de 1988 como em outras leis que versam sobre o direito à Educação, seus princípios e sobre a competência dos entes federados para a sua efetivação.

Dispóe a Constituição Federal de 1988:

Art. 206. O ensino será ministrado com base nos seguintes princípios:

I - igualdade de condiçóes para o acesso e permanência na escola;

II - liberdade de aprender, ensinar, pesquisar e divulgar o pensamento, a arte e o saber;

III - pluralismo de ideias e de concepçóes pedagógicas

$[\ldots]$ 
IV - gratuidade do ensino público em estabelecimentos oficiais;

[...]

VI - gestão democrática do ensino público, na forma da lei;

$[\ldots]$

Em sentido semelhante, dispóe o artigo $3^{\circ}$ da Lei de Diretrizes e Bases da Educação Brasileira - Lei no 9.394 de 20 de dezembro de 1996 (LDB). A LDB inclui outros princípios em relação aos já apresentados pela Constituição Federal de 1988, como o respeito à liberdade e apreço à tolerância

O Estatuto da Criança e do Adolescente (ECA - Lei no 8069 de 13 de julho de 1990) também prevê direitos relacionados à educação:

Art. 53. A criança e o adolescente têm direito à educação, visando ao pleno desenvolvimento de sua pessoa, preparo para o exercício da cidadania e qualificação para o trabalho, assegurando-se-lhes [sic]:

I - igualdade de condiçóes para o acesso e permanência na escola;

II - direito de ser respeitado por seus educadores;

III - direito de contestar critérios avaliativos, podendo recorrer às instâncias escolares superiores;

IV - direito de organização e participação em entidades estudantis;

$[\ldots]$

Parágrafo único. É direito dos pais ou responsáveis ter ciência do processo pedagógico, bem como participar da definição das propostas educacionais.

Os incisos II e III e o parágrafo único são expressóes da gestão democrática do ensino, prevista tanto pela Constituição Federal de 1988 como pela LDB. Ocorre que a gestão democrática é apenas um princípio genérico na $\mathrm{CF} / 1988$, expressa no artigo 216, inciso VI, citado anteriormente. O Estatuto, por sua vez, possibilita às crianças, aos adolescentes e às suas famílias o questionamento acerca das decisóes escolares e a participação na definição de práticas educacionais (MOREIRA e SALLES, 2015, p. 184).

São diversos os princípios norteadores do Direito à Educação, dispostos principalmente na Constituição Federal de 1988, na LDB no 9.394/1996 (LDB) e no Estatuto da Criança e do Adolescente. No capítulo 3, abordar-se-á como as escolas objeto de estudo se comportam em relação a esses princípios, notadamente o da Gestão Democrática.

O Estatuto mostra ter maior atenção aos direitos educacionais de crianças e adolescentes relacionados à democracia no ambiente escolar quando comparado com a Constituição Federal de 1988.

No que diz respeito ao dever do Estado com a educação, a efetivação se dá, conforme a CF/1988, por:

Art. 208. O dever do Estado com a educação será efetivado mediante a garantia de:

I - educação básica obrigatória e gratuita dos 4 (quatro) aos 17 (dezessete) anos de idade, assegurada inclusive sua oferta gratuita para todos os que a ela náo tiveram acesso na idade própria;

II - progressiva universalização do ensino médio gratuito; 
III - atendimento educacional especializado aos portadores de deficiência, preferencialmente na rede regular de ensino;

IV - educação infantil, em creche e pré-escola, às crianças até 5 (cinco) anos de idade;

V - acesso aos níveis mais elevados do ensino, da pesquisa e da criação artística, segundo a capacidade de cada um;

VI - oferta de ensino noturno regular, adequado às condiçóes do educando;

VII - atendimento ao educando, em todas as etapas da educaçáo básica, por meio de programas suplementares de material didático escolar, transporte, alimentação e assistência à saúde. ${ }^{3}$

Prevê, ainda, o parágrafo $2^{\circ}$ do artigo 208 que "o náo-oferecimento [sic] do ensino obrigatório pelo Poder Público, ou sua oferta irregular, importa responsabilidade da autoridade competente". Tendo em vista o pacto federativo e a atribuiçáo de competências constitucionais, importa fazer uma breve análise acerca da cooperação entre entes federados para a oferta de educação básica.

Competências Federativas "são parcelas de poder atribuídas, pela soberania do Estado Federal, aos entes políticos, permitindo-lhes tomar decisôes no exercício regular de suas atividades, dentro do círculo pré-traçado pela Constituição da República." (BULOS, p. 975, 2015).

O Constituinte dividiu as competências em administrativas (ou materiais) e legislativas. Interessa, para a presente análise, entender as competências privativas, concorrentes e comuns.

Em matéria educacional, as competências privativas e concorrentes são de ordem legislativa ao passo que as comuns são de ordem administrativa ou material (ARAÚJO, 2010).

A competência privativa "contém a nota da delegabilidade. Por seu intermédio, o ente político que a titulariza transfere, no todo ou em parte, determinada parcela de poder para a execução de tarefas de outra entidade federativa." (BULOS, p. 979, 2015).

A concorrente ocorre quando mais de um ente federativo detém o poder de legislar sobre a matéria, ficando a cargo da União a tarefa de estipular normas gerais. A comum, por fim, é conferida simultaneamente a todas as entidades políticoadministrativas, de modo que União, Estados, Distrito Federal e Municípios cooperam na execução de tarefas e objetivos que lhes são correlatos. (BULOS, 2015).

Em matéria de Educação, o Constituinte fixou competências para União, Município, Estados e Distrito Federal: a competência privativa para legislar sobre diretrizes e bases da educação nacional fica a cargo da União (artigo 22, inciso XXIV $\mathrm{CF}$ ); já competência para legislar sobre educação para além das diretrizes e bases é concorrente entre a União, Estados e Distrito Federal (artigo 24, inciso IX, CF);

3 A LDB (artigo $4^{\circ}$ ) e o ECA (artigo 54) fazem previsões em sentido semelhante. 
por fim, é competência comum da Uniáo, dos Estados, do Distrito Federal e dos Municípios proporcionar os meios de acesso à educação (artigo 23, inciso V, CF).

A Carta Magna, em seu artigo 211, definiu que os entes deveriam organizar seus respectivos sistemas de ensino em regime de colaboração. À União, cabe o sistema federal de ensino, o financiamento de instituiçôes públicas federais e a funçáo redistributiva e supletiva de recursos financeiros. Municípios devem atuar prioritariamente na educação infantil (zero a cinco anos) e no ensino fundamental ( $1^{\circ}$ ao $9^{\circ}$ ano), enquanto Estados e Distrito Federal atuam prioritariamente no ensino fundamental e médio ( $1^{\circ}$ ao $3^{\circ}$ ano). O Ensino Fundamental recebe atenção reforçada, sendo prioridade tanto de municípios como de estados e Distrito Federal.

Nos termos do parágrafo único do artigo $23 \mathrm{da} \mathrm{CF} / 1988$, "Leis complementares fixarão normas para a cooperação entre a União e os Estados, Distrito Federal e os Municípios, tendo em vista o equilíbrio do desenvolvimento e do bem-estar em âmbito nacional”.

Araújo (2018) aponta que a despeito de terem sido verificados avanços na Carta Magna e na legislação infraconstitucional em matéria de coordenação e cooperação federativa no tocante à Educação, não houve, de fato, a regulamentação prevista pelo artigo 23. Não houve definição de como os entes federativos atuariam, em ações integradas, na prestação de serviços educacionais por meio do regime de colaboraçáo (artigo 211, CF/1988), de modo a possibilitar a oferta educacional com padrão de qualidade (art. 206, VII, CF/1988).

Tal falta de regulamentação representa um entrave ao pleno funcionamento do pacto federativo nesse aspecto.

\subsection{As escolas e os militares}

A Constituição Federal de 1988 deu tratamento progressista a diversos temas. Quanto aos assuntos civil-militares, não se pode afirmar o mesmo. Foi mantida boa parte das disposiçôes militares não democráticas trazidas pela Constituição Autoritária anterior (ZAVERUCHA, 2010).

Para Lima e Oliveira (2016), são três os alicerces ideológicos do militarismo: hierarquia, disciplina e um inimigo a ser combatido.

Há sentido em um modelo militarizado para defesa da soberania do país. Já no tocante à segurança interna de um Estado Democrático de Direito, é difícil conceber a mesma lógica aplicada à defesa da soberania, isto é, a lógica militar.

Os organismos militares no Brasil englobam não somente as Forças Armadas, constituídas pela Marinha, pelo Exército e pela Aeronáutica, mas também alguns órgãos pertencentes à segurança pública, a saber: as polícias militares e os corpos de bombeiros militares. Dispóe a Constituição Federal de 1988:

Art. 142. As Forças Armadas, constituídas pela Marinha, pelo Exército e pela Aeronáutica, são instituiçóes nacionais permanentes e regulares, organizadas com base na hierarquia e na disciplina, sob a autoridade suprema 
do Presidente da República, e destinam-se à defesa da Pátria, à garantia dos poderes constitucionais e, por iniciativa de qualquer destes, da lei e da ordem. [...]

Art. 144. A segurança pública, dever do Estado, direito e responsabilidade de todos, é exercida para a preservação da ordem pública e da incolumidade das pessoas e do patrimônio, através dos seguintes órgãos:

$[\ldots]$

$\mathrm{V}$ - polícias militares e corpos de bombeiros militares.

$[\ldots]$

$\$ 5^{\circ}$ Às polícias militares cabem a polícia ostensiva e a preservação da ordem pública; aos corpos de bombeiros militares, além das atribuiçóes definidas em lei, incumbe a execução de atividades de defesa civil.

É possível observar a atuação dessas instituiçốes com outras finalidades, como na Educação, na incorporação de atletas de alto rendimento em programas das Forças Armadas (BRASIL, [2019?a]) e no Programa Educacional de Resistência às Drogas e à Violência - Proerd - que visa prevenir ou reduzir o uso de drogas e a violência (TOCANTINS, [201-?]).

As escolas militarizadas são uma expressão da presença de militares fora de suas atribuiçôes. Destaca-se a disciplina a qual os organismos militares estão submetidos tende a ser aplicada nas escolas militarizadas, como será abordado adiante.

Cabe, aqui, fazer a distinçáo entre escolas militares e militarizadas. De acordo com Matuoka (2019), as militarizadas nascem com a gestáo da Secretaria de Educação e, posteriormente, passam para a gestão de instituiçóes militares, tornando-se escolas cívico-militares. Nesse modelo, militares e civis partilham a administraçáo escolar.

As escolas militares, por sua vez, têm autonomia para montar sua estrutura pedagógica e podem contar com militares professores. Contam com recursos do Ministério da Educação e Ministério da Defesa. Existem 14 colégios militares no Brasil ${ }^{4}$. O Regulamento dos Colégios Militares (R-69) aponta que:

Art. 20 Os $\mathrm{CM}$ são organizaçóes militares (OM) que funcionam como estabelecimentos de ensino (EstbEns) de educaçáo básica, com a finalidade de atender ao Ensino Preparatório e Assistencial.

[...]

$\$ 2^{\circ}$ Os CM subordinam-se, diretamente, à Diretoria de Ensino Preparatório e Assistencial (DEPA) e destinam-se a:

I - atender aos dependentes de militares de carreira do Exército, enquadrados nas condiçôes previstas neste Regulamento, e aos demais candidatos, por meio de processo seletivo; e II - capacitar os alunos para o ingresso em estabelecimento de ensino militares, com prioridade para a Escola Preparatória

4 Colégio Militar do Rio de Janeiro, Colégio Militar de Porto Alegre, Colégio Militar de Fortaleza, Colégio Militar de Manaus, Colégio Militar de Brasília, Colégio Militar de Recife, Colégio Militar de Salvador, Colégio Militar de Belo Horizonte, Colégio Militar de Curitiba, Colégio Militar de Juiz de Fora, Colégio Militar de Campo Grande, Colégio Militar de Santa Maria, Colégio Militar de Belém e Colégio Militar de São Paulo [BRASIL, [2019?]b). 
de Cadetes do Exército (EsPCEx), e para as instituiçóes civis de ensino superior.

Um dos objetivos dos Colégios Militares é a capacitação para o ingresso em estabelecimentos de ensino militares e, consequentemente, na carreira militar. Os colégios militarizados/cívico-militares, por sua vez, destinam-se à formaçáo civil.

A despeito de o ensino militar para a formação de soldados existir desde o Brasil colonial, é apenas com o fracasso do ensino público que a filosofia militar é transplantada, ou ao menos cogitada, para escolas de formação civil (FILHO, ROCHA e SANTOS, 2017).

Houve tentativas fracassadas de criação de um Colégio Militar em 1840, por parte do Marquês de Olinda, e em 1853 e 1862, por parte do Duque de Caxias. Todavia, foi apenas no final do Império, por meio do Decreto no 10.202 de março de 1889, que houve a criação do Imperial Colégio Militar, primeiro Colégio Militar no país (BRASIL, 2015).

Surge, primeiro, o Colégio Militar. Este trabalho será feito a partir de análises do modelo escolar militarizado, cuja expansáo no Brasil se deu em um cenário traçado a partir da década de 1990 , em meio a reformas gerenciais dentre as quais a da Educação é uma das mais significativas (GUIMARÃES, 2017).

A escola pública brasileira transformou-se nos últimos 30 anos, influenciada tanto pelo processo de universalização da Educaçáo como pela Reforma Gerencial instituída pelo Governo Fernando Henrique Cardoso. O financiamento da educaçáo pública não acompanhou essa numerosa expansáo em termos de oferta de vagas (GUIMARÃES, 2017).

A ampliação do acesso à educação básica não foi implementada levando em consideração a qualidade do ensino, mas surgiu tão somente com o objetivo de minimizar tensôes sociais e atenuar a pobreza. Nesse contexto, passou-se a falar em "apagáo educacional" no Brasil.

A tese do "apagáo educacional" foi utilizada, segundo (SANTOS, 2012:7), como justificativa para o "sequestro" da escola pública. A tese de que a escola pública projetada na transição do regime ditatorial para a democracia havia fracassado, tornou-se a principal justificativa para a emergência de novos modelos de gestáo do trabalho escolar inseridos nos sistemas estaduais e municipais de ensino. De acordo com entusiastas dos novos modelos de gestão do trabalho escolar, estes deveriam proporcionar a diminuição da violência, indisciplina, evasão e a repetência. É neste contexto que se verifica a difusão do novo modelo de gestão militarizada das escolas públicas [...] (GUIMARÃES, p. 9, 2017)

O contexto no qual ocorre a expansão da escola militarizada surge aliando-se importantes fatores: herança do regime ditatorial, uma escola pública considerada fracassada e o anseio por disciplina e reduçáo da violência.

Sobre a disciplina, um dos pilares do modelo, Pinheiro e Lucena asseveram que: 
A rígida disciplina imposta aos estudantes e aos professores destas escolas se justifica diante da necessidade de fazer com que estes jovens incorporem os valores dominantes e acreditem que a educação para ter qualidade depende da obediência cega as hierarquias e às normas estabelecidas. Qualquer questionamento pode significar o fracasso da escola, do professor e do aluno. (2014, p. 552-553)

A defesa da disciplina instituída em colégios militares e militarizados se constrói a partir de uma falácia segundo a qual só há educação de qualidade a partir da disciplina inquestionável.

No campo da educação formal, observamos que a prática pedagógica adotada na formação profissional militar - pedagogia militar - cumpre o papel da conformação psicofísica, ética e moral do trabalhador por meio da coerção. Para tal, utiliza o medo, a violência a fim de introjetar valores pautados na hierarquia e na disciplina, próprios dos espaços da caserna. $\mathrm{O}$ humano que essa pedagogia pretende forjar é submisso, obediente e conformado às condiçóes precárias e à ausência de direitos. Nesse sentido, cumpre o propósito do sistema vigente que demanda de instituiçóes de controle social responsáveis pela manutenção do status quo. Obviamente, quando aplicada à Educação Básica, esta pedagogia só faz sentido para as camadas subalternas, especialmente aquelas pauperizadas, residentes das periferias urbanas, precarizadas (VEIGA e SOUZA, 2019, p. 17-18)

Um estudo realizado por Veiga e Souza (2019), com base em questionários aplicados a 983 alunos e ex-alunos do Curso de Formação de Soldados da Polícia Militar do Estado do Rio de Janeiro (CFSd/PMERJ) constatou que o modelo de disciplina com base no uso da pedagogia militar náo é consenso nem entre os sujeitos investigados, e evidencia que tal pedagogia não é suficiente para a captura da subjetividade humana, de tal modo que os sujeitos internalizam, cegamente, a defesa incondicional de padróes e valores militares. Essa pedagogia tem impactado negativamente boa parte dos sujeitos a ela submetidos, ainda que na formação militar de carreira (VEIGA e SOUZA, 2019, p.18).

Se a disciplina proposta pela pedagogia militar encontra problemas de aceitação e tem seu benefício questionado mesmo dentre sujeitos que passaram pela formação de Soldado da Polícia Militar, qual é o sentido de incorporá-la à educação básica?

\subsection{Programa Nacional das Escolas Cívico-Militares}

No contexto da expansão do modelo escolar militarizado, o Governo Federal, por meio do Decreto no 10.004 de 5 de setembro de 2019, lançou o Programa Nacional das Escolas Cívico-Militares (PECIM),

[...] que apresenta um conceito de gestão nas áreas educacional, didáticopedagógica e administrativa com a participação do corpo docente da escola e apoio dos militares. A proposta é implantar 216 Escolas Cívico-Militares em todo o país, até 2023, sendo 54 por ano. (BRASIL, 2019c) 
Trata-se de programa desenvolvido pelo Ministério da Educação com o apoio do Ministério da Defesa e implementação em colaboração com Estados, Municípios e Distrito Federal (art. $1^{\circ}, \$ 1^{\circ}$ do Decreto no 10.004/2019).

Ainda conforme o Decreto que institui o PECIM, existe uma Subsecretaria de Fomento às Escolas Cívico-Militares na Secretaria de Educação Básica do Ministério da Educação que atua na coordenação estratégica do PECIM e implementação das ações decorrentes (art. 19).

Cabe ao MEC o apoio técnico e financeiro ao Ministério da Defesa e aos entes federados que participarem do programa, a fim de subsidiar a execução do programa, de acordo com o artigo 21.

Em relação à localização das escolas enquanto órgáos, o artigo 23 esclarece que não haverá subordinação técnico-administrativa ou vinculação das escolas ao Ministério da Defesa. As instituiçóes de ensino permanecem subordinadas às respectivas Secretarias de Educação.

O Tocantins foi um dos Estados da federação a aderir ao PECIM, conforme aponta o mapa a seguir.

Figura 1 - Mapa de escolas que aderiram ao PECIM em 2020 por estado da federação

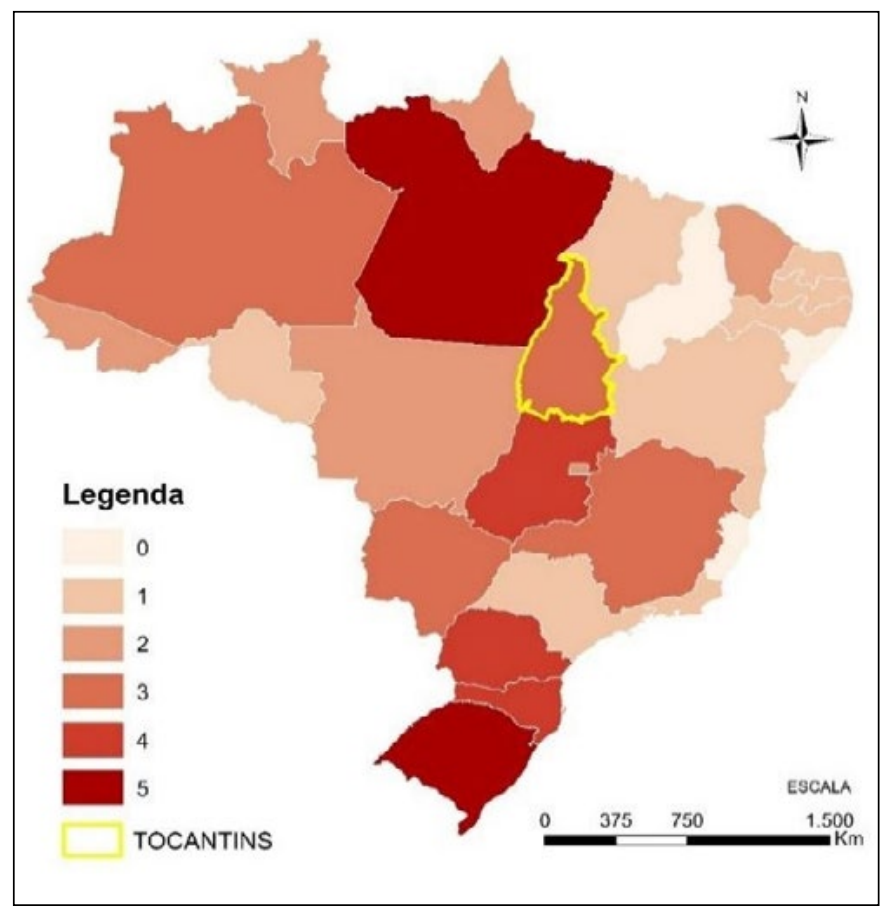

Fonte: elaborado pela autora a partir de dados cartográficos do INPE (BRASIL, 2013) e de dados sobre as escolas do MEC (BRASIL, 2020) 
No âmbito estadual, a SEDUC instituiu, por meio da Portaria no 2423 de 22 de setembro de 2019, a Unidade Técnica Executiva de Estudos de Oferta e Modalidades Especiais de Ensino - UTE, que tem como uma de suas competências a colaboração e acompanhamento do PECIM no território do Estado do Tocantins.

O Decreto no 10.004/2019 dispóe, em seu artigo $1^{\circ}$, que a finalidade do programa é promover a melhoria na qualidade da educaçáo básica no ensino fundamental e no ensino médio.

Conforme o sítio oficial do Programa, os militares atuarão no apoio às gestóes escolar e educacional, ao passo que professores e profissionais da educação permaneceráo na linha de atuaçáo didático-pedagógica (BRASIL, 2019c).

Somando-se às iniciativas locais, é possível perceber que o modelo se encontra em franca expansão, e por isso deve ser discutido em trabalhos acadêmicos.

\section{AS ESCOLAS MILITARIZADAS NO TOCANTINS}

É necessário analisar se a proposta de transformaçáo das escolas em cívico-militares sem alteraçóes na CF/1988 e na legislação federal e sem base na representaçáo política e na regra da maioria atende ao interesse público, pois este deve ser previsto em lei. Em uma primeira análise, essa estruturação das escolas militarizadas parece se chocar com os princípios da legalidade - art. 37, CF/1988 - e da finalidade pública - art. 20 da Lei 9.784 de janeiro de 1999 (XIMENES, STUCHI e MOREIRA, 2019).

De acordo com a legalidade, "na Administração Pública não há liberdade nem vontade pessoal. Enquanto na administração particular é lícito fazer tudo que a lei não proíbe, na Administração Pública só é permitido fazer o que a lei autoriza." (DI PIETRO, 2014, p. 65).

A finalidade pública determina que os atos da administraçáo devem sempre ser pautados pelo alcance do fim público expresso por lei. Quando a finalidade não está prevista em diploma legal, os atos com fim diverso àquele explicita ou implicitamente previsto na regra de competência poderão ser invalidados por desvio de finalidade - Lei da Ação Popular no 4717 de 29 de junho de 1965, artigo 2o, parágrafo único, "e" (XIMENES, STUCHI e MOREIRA, 2019).

\subsection{Histórico}

No Tocantins, o modelo surge em 18 de agosto de 2009, quando foi fundado o então Colégio Militar de Palmas - CMP - a partir de uma parceria entre a Polícia Militar do Tocantins e a Secretaria Estadual de Educação. Surge, conforme aponta o sítio oficial da PM-TO, com a missão de "contribuir para a educação de jovens tocantinenses, visando um ensino de qualidade e a formaçáo cidadã e integral dos discentes" (TOCANTINS, 2020a, texto digital). 
No tocante às razóes por trás da implantação do modelo, deve-se analisar as justificativas apresentadas pelo Estado, por meio de documentos e de seus agentes que participaram do processo, e as justificativas históricas.

Rocha, Silva Filho e Santos (2017), ao entrevistarem Cecília Maria de Oliveira Silva, uma das pioneiras da fundação do modelo no Tocantins, questionaramna sobre os motivos da implantação do modelo no Estado, tendo apontado a entrevistada que:

A polícia queria um ensino de qualidade, até porque eles tinham filhos. Assim, pensando como era sucesso em outros estados aqui também deveria ser. O colégio militar estava dando resultado em outros estados e como eles tem academia dentro do quartel, então foi surgindo a ideia e amadurecendo até que então resolveram implantar. (SILVA, 2016 apud ROCHA, SILVA FILHO e SANTOS, 2017, p. 16)

É possível observar, como bem asseveram os autores, que a fala da entrevistada guarda consonância com a justificativa apresentada pelo Estado para a implantação. É fundamental, todavia, fazer a leitura histórica do evento:

[...] é válido lembrar que os motivos de implantação de um colégio militar no Tocantins seguem uma tradição bem específica. Esta tradição remonta ao prussianismo de Frederico I (um colégio para filhos de militares) e ao Brasil imperial: uma educação de qualidade, dado o fracasso das demais instituiçóes. O motivo é sempre um heroísmo redentor. Vem sempre para salvar o processo educacional que está perdido. Esses são os mesmos motivos usados para implantação de novos colégios militares em quase todas as situaçôes no Brasil. (ROCHA, SILVA FILHO E SANTOS, 2017)

A militarização de escolas no Tocantins surge, dessa forma, com justificativa semelhante à da implantação em outros estados: um ato de heroísmo para melhorar a qualidade e trazer disciplina para a até entâo falida educaçáo pública.

Desde a implantaçáo do Colégio Militar de Palmas, houve crescimento considerável na quantidade de escolas estaduais tocantinenses administradas conforme o modelo. Atualmente, há 15 escolas estaduais militarizadas, das quais 3 foram implantadas por meio do PECIM, conforme apontam as tabelas abaixo. 
Tabela 1 - Escolas estaduais militarizadas no Tocantins

\begin{tabular}{|c|c|c|}
\hline NOME DA INSTITUIÇÁO5 & LOCALIZAÇÃO & NÍVEL DE ENSINO \\
\hline Doutor José Aluisio da Silva Luz & Araguaína & Médio \\
\hline Professora Antonina Milhomem & Araguatins & Médio \\
\hline Centro Estadual de Educação La Salle & Augustinópolis & Fundamental I e II ( $4^{\circ}$ ao $9^{\circ}$ ano $)$ \\
\hline Jacy Alves de Barros & Arraias & Fundamental II ( $\left(6^{\circ}\right.$ ao $9^{\circ}$ ano $)$ \\
\hline João XXIII & Colinas & Fundamental II e Médio \\
\hline Dona Anaídes Brito Miranda & Guaraí & Fundamental II e Médio ( 1 e $2^{\circ}$ ano) \\
\hline Presidente Costa e Silva & Gurupi & Fundamental II e Médio (1º ano) \\
\hline Professora Maria Guedes & Palmeirópolis & Fundamental II e Médio ( $1^{\circ}$ ano) \\
\hline Unidade I & Palmas & Fundamental II \\
\hline Unidade II & Palmas & Médio \\
\hline Diaconizio Bezerra da Silva & Paraíso & Fundamental II e Médio \\
\hline Custódia da Silva Pedreira & Porto Nacional & $\begin{array}{l}\text { Fundamental I }\left(5^{\circ} \text { ano }\right) \text {, } \\
\text { Fundamental II e Médio (10 e } 2^{\circ} \\
\text { ano) }\end{array}$ \\
\hline
\end{tabular}

Fonte: Elaborada pela autora a partir de dados da Polícia Militar do Estado do Tocantins (2020b)

Tabela 2 - Escolas estaduais militarizadas por meio do PECIM

\begin{tabular}{l|l|l}
\hline \multicolumn{1}{c|}{ NOME DA INSTITUIÇÃO } & LOCALIZAÇÃO & \multicolumn{1}{c}{ NÍVEL DE ENSINO } \\
\hline Escola Estadual Hercília Carvalho da Silva & Gurupi & Fundamental II e Médio \\
\hline Escola Estadual Maria dos Reis Alves Barro & Palmas & Fundamental I e II e Médio \\
\hline Escola Estadual José Operário & Paraíso & Fundamental II e Médio \\
\hline
\end{tabular}

Fonte: Elaborada pela autora a partir de dados do Educa Mais Brasil (2020)

Esse número tende a crescer nos próximos anos, já que há iniciativas para a ampliação do modelo por parte do Governo Estadual e do Governo Federal - que atingirá a rede pública tocantinense.

Em setembro de 2019, o Governador do Tocantins manifestou a intenção de implantar 33 colégios militares no Estado, justificando que a implantação é associada à disciplina (TOCANTINS, 2019a).

As parcerias de escolas públicas com órgãos militares são diversas. Ocorrem a nível municipal, estadual e federal. Em Palmas, Tocantins, a Escola de Tempo Integral Caroline Campelo possui parceria com o Exército Brasileiro (BRASIL, 2017) e a Escola de Tempo Integral (ETI) Almirante Tamandaré possui parceria com a Marinha do Brasil (BRASIL, 2019e), sendo ambas escolas públicas municipais.

5 Todas as escolas são precedidas de "Colégio Militar do Estado do Tocantins" 
São muitas as questôes que permeiam a gestão escolar militarizada. Considerando-se as explanaçóes até agora feitas sobre o modelo, fica claro que as escolas são, antes de tudo, civis, e que as parcerias com a Polícia Militar do Tocantins surgiram com o principal objetivo de fortalecer a disciplina escolar. Nesse sentido, é relevante verificar qual é o cenário institucional no âmbito desses colégios e como a Polícia Militar está inserida nesse contexto.

\subsection{Normativas acerca dos Colégios Militares do Tocantins}

Há três legislaçôes principais que tratam Colégios Militares: Lei Complementar $\mathrm{n}^{\circ}$ 79, de 27 de abril de 2012, que dispóe sobre a organização básica da Polícia Militar do Estado do Tocantins; Lei Complementar no 83, de 4 de setembro de 2012, que dispóe sobre o Colégio da Polícia Militar do Estado do Tocantins; e Decreto $\mathrm{n}^{\circ} 5.819$, de 21 de maio de 2018, que dispóe sobre a gestão compartilhada das unidades escolares objeto da parceria entre a Secretaria da Educação, Juventude e Esportes e a Polícia Militar do Estado do Tocantins - PMTO.

Apesar da nomenclatura adotada, os colégios possuem gestáo compartilhada e não são militares. São, na verdade, militarizados - ou cívico-militares.

A lei de organizaçáo básica da Polícia do Tocantins - LC no 79/2012 dispóe, em seu artigo $1^{\circ}$, que o órgão se destina à preservação da ordem pública e à realizaçáo do policiamento ostensivo no território do Estado. $\mathrm{O}$ artigo $2^{\circ}$ enumera, em seus dez incisos, quais são as competências da PM-TO:

\section{Art. 2o Compete à PMTO:}

I - planejar, organizar, dirigir, supervisionar, coordenar, controlar e executar as açôes de polícia ostensiva e de preservação da ordem pública;

II - executar, com exclusividade, ressalvadas as missóes peculiares às ForçasArmadas, o policiamento ostensivo fardado para prevenção e repressão dos ilícitos penais e infraçôes definidas em lei, bem como as açôes necessárias ao pronto restabelecimento da ordem pública;

III - atuar de maneira preventiva, repressiva ou dissuasiva em locais ou áreasespecíficas em que ocorra ou se presuma possível a perturbação da ordem pública;

IV - exercer o policiamento ostensivo e a fiscalização de trânsito nas rodovias estaduais e, no limite de sua competência, nas vias urbanas e rurais, além de outras açóes destinadas ao cumprimento da legislação de trânsito;

$\mathrm{V}$ - desempenhar, nos limites de sua competência, a polícia administrativa do meio ambiente, na fiscalização, constatação e autuação de infraçóes ambientais e outras açóes pertinentes, e colaborar com os demais órgáos ambientais na proteção do meio ambiente;

VI - proceder, nos termos da lei, à apuração das infraçóes penais de competência da polícia judiciária militar;

VII - planejar e realizar açôes de inteligência destinadas à prevenção criminal e ao exercício da polícia ostensiva e da preservação da ordem pública na esfera de sua competência;

VIII- realizar a guarda externa de estabelecimentos penais e as missóes de segurança de dignitários em conformidade com a lei; 
IX - garantir o exercício do poder de polícia pelos Poderes e Órgãos Públicos do Estado, especialmente os das áreas fazendária, sanitária, de uso e ocupação do solo, do patrimônio cultural e do meio ambiente;

$\mathrm{X}$ - efetuar o patrulhamento aéreo no âmbito de sua competência.

Dentre as competências da PM-TO, nenhuma está relacionada à educação ou à gestão escolar.

A única menção feita aos Colégios Militares, ocorre no artigo 33: "Os Colégios Militares são órgãos especiais da PMTO". Chama atenção o fato de escolas civis integrarem, conforme a Lei Complementar, a estrutura de um órgão da Segurança Pública.

Órgãos são, na lição de Bandeira de Mello (2012, p. 144), "unidades abstratas que sintetizam os vários círculos de atribuições do Estado". Ainda conforme o autor, os órgãos não têm personalidade jurídica e se comportam como simples repartiçóes internas da pessoa jurídica a qual integram.

A LC no 79/2012 trata, no capítulo II, sobre a estrutura básica da PM-TO, que se organiza a partir de órgãos de direção, de apoio, de execução e especiais, conforme o artigo $4^{\circ}$. Os artigos subsequentes destinam-se a definir cada tipo de órgão mencionado na organização. Estranhamente, a lei não define o que é um órgão especial.

A doutrina administrativista ocupa-se com a definição de diversos tipos de órgãos, como os de controle e os consultivos. $\mathrm{Na}$ doutrina e legislação pesquisadas, todavia, não se encontrou qualquer definição acerca de órgáos especiais.

Há, assim, uma lacuna entre o reconhecimento dos Colégios da Polícia Militar enquanto órgáos especiais da PM-TO pela LC no 79/2012 e a falta de parâmetros sobre o que é um órgão especial.

Na LC no 83/2012 há menção, novamente, aos colégios enquanto órgãos especiais da PM-TO:

Art. 2o O Colégio da Polícia Militar do Estado do Tocantins, órgão especial integrante da organização básica da PMTO, é constituído por unidades escolares a ele incorporadas, integrantes da Rede Estadual ou da Rede Municipal de Ensino.

Semelhante à LC no 79/2012, não há qualquer definição ou parâmetro sobre o que é um órgão especial.

Questiona-se: a lotação dos colégios militares pode ser alterada na estrutura administrativa do Estado em virtude da LC no 79/2012 e da gestão compartilhada - que tem vigência por cinco anos, conforme os termos de cooperação técnica estudados - das unidades?

Após ser demandada via correio eletrônico, a SEDUC informou que os colégios pertencem, simultaneamente, à estrutura da SEDUC e da PM-TO. A justificativa apresentada é de que o quadro de servidores dos colégios é composto, em parte, por servidores militares, e por isso os colégios fazem parte, também, da 
estrutura organizacional da PM-TO. Parece frágil a justificativa legal que considera os colégios como parte da estrutura organizacional da PM-TO

$\mathrm{O}$ artigo $2^{\circ}, \mathbb{S} 1^{\circ}$, da LC $\mathrm{n}^{\circ} 83 / 2012$ dispóe que a militarização da escola ocorrerá mediante lei de criação, no caso de nova unidade escolar, ou por meio de convênio, em se tratando de unidades escolares já existentes. No $\$ 2^{\circ}$, são traçados parâmetros para a celebraçáo desse convênio. $\mathrm{O}$ artigo $3^{\circ}$ define quais são os objetivos do Colégio da Polícia Militar:

Art. $3^{\circ}$ O Colégio da Polícia Militar do Estado do Tocantins tem por objetivo: I - o estímulo:
a) do amor à Pátria;
b) da disciplina consciente;
c) do respeito aos direitos humanos;
d) dos atributos físicos;
e) dos talentos para a carreira militar.
II - a valorização das tradições nacionais e regionais.

Predominam os ideais militares, apesar de a instituição ser, sobretudo, de formação civil. $\mathrm{O}$ estímulo da disciplina, sempre apontada na defesa do modelo escolar militarizado, também é mencionado entre os objetivos do órgão. Não há, em contrapartida, qualquer objetivo relacionado diretamente com educação e seus correlatos, como capacitação, formaçáo, conhecimento ou gestáo escolar.

O Decreto no 5819/2018, que dispóe acerca da gestão compartilhada das unidades escolares objeto da parceria entre a SEDUC e a PM-TO, prevê, em seu artigo $1^{\circ}$, parágrafo único, que as parcerias de cada colégio devem ser celebradas em termo próprio, a fim de contemplar as peculiaridades de cada unidade, como veremos a seguir.

\subsection{Atos de instituiçáo e análise das estruturas dos colégios}

Os documentos utilizados neste trabalho foram solicitados por meio de ofício e por meio do Serviço de Informação ao Cidadáo (SIC) do Governo do Tocantins, e foram direcionados pela SEDUC-TO e pela PM-TO. Os pedidos incluíam todos os documentos referentes às escolas estaduais militarizadas. Todavia, tanto a SEDUC como a PM não os disponibilizaram inteiramente. $\mathrm{O}$ estudo que gerou o presente artigo teve como limitação as dificuldades relativas ao acesso à informação.

Conforme consta no sítio oficial da Polícia Militar do Estado do Tocantins, o Colégio Militar de Palmas (CMP), primeira unidade do modelo militarizado no estado, foi instalado em 18 de agosto de 2009, por meio de parceria entre a PMTO e a SEDUC (TOCANTINS, 2020a). Não há nenhuma menção ao seu ato instituidor. $\mathrm{O}$ documento que institui a parceria referente à primeira unidade data de 2015, como veremos a seguir. Há uma lacuna de 6 anos entre o surgimento da primeira unidade e o documento que dispóe sobre a parceria.

Dentre os documentos disponibilizados para esta pesquisa, o único que contempla a parceria referente à instituição do Colégio Militar de Palmas é o termo de cooperação técnica no 008/2015, que abrange outras três unidades (Araguaína, 
Arraias e Palmas - unidade II). Além desse, a presente análise apoia-se em outros dois termos de cooperação técnica, o no 11/2019 e o no 017/2018, referentes às unidades de Augustinópolis e Guaraí, respectivamente.

Abordado no tópico anterior, o Decreto no 5819/2018 - que prevê termo próprio para cada colégio, a fim de contemplar as peculiaridades de cada unidade ainda não existia quando da publicação do termo de cooperação técnica no 2015, que dispóe acerca das unidades de Araguaína Arraias e Palmas, motivo por que não se pode apontar irregularidade em virtude de o mesmo termo reger a parceria de quatro escolas.

Há previsão de Regimento Interno e Regulamento Disciplinar próprios dos colégios militares, devendo, todavia, serem aprovados no Conselho Estadual de Educação. Conforme esclarecimentos prestados pela SEDUC via correio eletrônico, foi elaborado um Regimento Escolar Padrão dos Colégios Militares do Estado do Tocantins, tendo sido aprovado pelo Conselho Estadual de Educação. Tal Regimento, todavia, ainda não foi publicado no Diário Oficial do Estado e por isso não foi disponibilizado o acesso para o presente trabalho. Já o Regimento Disciplinar é produzido pelas unidades escolares, tendo cada escola o seu próprio Regimento. Esses regimentos disciplinares não foram disponibilizados e, portanto, não serão objeto de análise no presente trabalho.

A partir dos documentos analisados, nota-se que a maior parte da gestáo escolar é feita pela PM-TO. Há diversos dispositivos que indicam delegação de competências, por parte da SEDUC, à PM-TO. Em todos os termos de cooperaçáo técnica analisados, fica claro que a SEDUC fornece a estrutura da escola, com todos os recursos financeiros que a sustentam, e recursos humanos para atuarem na docência e demais setores.

A PM-TO, por sua vez, fica responsável por gerir os recursos financeiros - oriundos da Educação -, e responder pela gestão pedagógica, disciplinar, administrativa e financeira das escolas. Assim, apesar de surgirem de uma parceria, em que os recursos de custeio são oriundos da Educaçáo e, portanto, civis, os órgãos são denominados Colégios da Polícia Militar.

De acordo com os termos de cooperação no 008/2015, no 17/2018 e no $11 / 2019$, há a designação de oficiais para assumirem as coordenaçóes das escolas. Com exceção do termo de cooperação técnica no 008/2015, há previsão de formação na área de educação para o cargo de coordenador pedagógico. Também o cargo de Direção das unidades escolares é atribuído a oficial da PM com formação na área educacional. As escolhas e nomeaçóes desses cargos são de competência do Comandante Geral da PM.

Nota-se, portanto, certa preponderância do militarismo, visto que todos os cargos de coordenaçáo e direçáo são oriundos da PM. Ou seja, os cargos centrais da gestão de direção escolar são atribuídos a um servidor, que é, antes de tudo, militar. Ainda que tenha formação educacional, pertence à carreira militar. Nesse sentido, Leal pondera que: 
Um padre ou uma freira podem ser excelentes professores, mas um convento que ensina música será sempre um convento. Assim como o fato de um coronel poder ter uma extraordinária didática não significa que um quartel que ensina matemática seja algo diferente de um quartel. $\mathrm{O}$ mesmo se diga de um partido que dá aulas de sociologia. Ele seguirá sendo um partido, nada além. Então, por quê confundir os papéis no tocante à educação pública? (2017, texto digital)

Percebe-se, assim, que o debate acerca da presença militar em escolas deve superar questôes simples ou puramente técnicas, como a existência ou não de formação específica.

Os docentes são oriundos da pasta da Educação, sendo responsabilidade da SEDUC. Os documentos estudados não dão margem a interpretação diversa. Não há, pois, previsão de militares para atuar na docência. Os docentes, no entanto, todos civis, no exercício de suas funçóes públicas relacionadas ao magistério, passam a cumprir suas atribuiçôes em um ambiente de organização militarizada, além de serem subordinados a agentes militares, o que também pode gerar impacto no campo do exercício do poder disciplinar e hierárquico da administração sobre seus servidores.

Em relação às divulgaçôes por quaisquer meios promovidas pelos colégios, os termos preveem a obrigatoriedade de constarem as identificaçóes do Governo do Estado e da SEDUC em igual destaque à da PM, o que pode resultar em confusáo quanto à origem e ao custeio das escolas.

Da análise de documentos, depreende-se que a estrutura organizacional é a seguinte: os cargos de direção e coordenação, que envolvem algum grau de decisão, são de responsabilidade da PM-TO. A SEDUC, por sua vez, entrega recursos humanos para atuarem na docência e apoio às coordenações, além de recursos financeiros - que compreendem a manutenção da estrutura e atividades escolares.

Parece, portanto, que a SEDUC assume papel secundário nas unidades escolares. Nota-se predominância do militarismo, causando, inclusive, confusão entre a população, que frequentemente se refere às unidades como "colégios da PM". É natural que haja essa confusão, já que a própria nomenclatura oficial adotada para se referir às unidades (colégio militar) transmite uma ideia errada sobre o que de fato são - ou deveriam ser - as instituiçóes.

\section{ANÁLISE JURÍDICA DAS NORMATIVAS DOS COLÉGIOS MILITARIZADOS}

Este capítulo aborda aspectos das normativas dos colégios militarizados tocantinenses, analisando-os a partir do direito educacional e constitucional amplamente trabalhados no capítulo 1. Em 2019, alguns aspectos polêmicos foram objeto de reforma, tendo havido avanços e limitaçóes. 
Os termos de parceria preveem a realização de processo seletivo para ingresso de novos alunos nos colégios militares, a ser realizado em parceria entre SEDUC e PM-TO.

A educação, conforme abordado no item 1.1 deste trabalho, obedece ao princípio da igualdade de condiçóes para acesso e permanência na escola. Ademais, é dever do Estado efetivar o direito à educação por meio da garantia de oferta da educaçáo básica obrigatória e gratuita na faixa etária entre quatro e dezessete anos.

Diferente do que ocorre com o ensino superior, cujo acesso depende da capacidade de cada um, não há que se falar em meritocracia no acesso à educação básica, que deve ser universal.

O processo seletivo impacta consideravelmente o desempenho de alunos, quando comparado com os demais da rede pública. Um estudo realizado por pesquisadores da Universidade Federal do Ceará sugere que o diferencial de desempenho dos alunos de escolas militares não se deve à militarização em si, mas outros fatores comumente ignorados ao se fazer a análise:

O desempenho diferenciado dos alunos de escolas militares em exames de proficiência como Prova Brasil ou ENEM tem dado força a visão que estas escolas deveriam servir de referencial para as escolas públicas no Brasil. No ENEM de 2014, por exemplo, a pontuação média em matemática das escolas militares estaduais foi de 514,15 pontos contra 454,13 nas não-militares, ao que se poderia inferir que este diferencial seja fruto do regime administrativo e organizacional diferenciado das primeiras (efeito escola). No entanto, esta atribuição direta do diferencial como efeito escola é questionável dado que seus alunos são diferenciados tanto por características familiares, como pelo acúmulo de conhecimentos (condição inicial), e o próprio processo de seleção que as escolas militares estabelecem. (BENEVIDES e SOARES, [201-], p. 1)

O processo de seleção deve ser entendido como um mecanismo que filtra os melhores alunos e deve ser ponderado na análise do desempenho escolar.

A fim de guardar compatibilidade com a LDB e assegurar a democratização do acesso à escola, foi anunciado, em 2019, o fim do processo seletivo dos colégios militares tocantinenses (TOCANTINS, 2019c).

Outra medida anunciada foi a alteração da nomenclatura dos colégios, por meio do Decreto no 6.005 de 29 de outubro de 2019, que dispóe sobre a gestão compartilhada das unidades escolares objeto da parceria entre a SEDUCTO - PMTO. Em caso de unidade que oferta somente ensino fundamental, ou fundamental e médio, passou-se a designar como "Colégio Estadual CívicoMilitar". Quanto às unidades que oferecem exclusivamente ensino médio, passouse a designar "Centro Estadual de Ensino Médio Cívico-Militar".

Conforme apontado pela Secretaria da Educação, a mudança na nomenclatura se deu porque as unidades são estaduais e cívicas, mas com metodologia militar. Logo, mudou-se a designação para aproximar-se da realidade, visto que tais escolas não são custeadas com recurso da Polícia Militar (TOCANTINS, 2019c). 
A modificação gerou, todavia, desconforto na comunidade escolar. Em protesto em Palmas, o deputado estadual Professor Júnior Geo (PROS) dialogou com pais e alunos dos colégios militares e afirmou que a decisão da SEDUC foi arbitrária, pois não dialogou com a comunidade escolar e nem foi precedida de estudo técnico (TOCANTINS, 2019d).

No contexto dos protestos, a Secretaria da Educação informou, em reunião com o Ministério Público do Estado do Tocantins e com representantes da comunidade escolar, que faria consulta pública para promover a alteração do nome das escolas (AF Notícias, 2019).

Em 11 de dezembro de 2019 foi publicado o Decreto no 6.022 que alterou, novamente, a nomenclatura das escolas militarizadas, dessa vez para "Colégio Militar do Estado do Tocantins", seguido do nome do homenageado - se houver - e revogou o Decreto no 6.005/2019. A nomenclatura que privilegia a alusão aos militares venceu, mesmo em se tratando de uma escola de formaçáo civil.

Ainda como reação às medidas impostas pela SEDUC, a Justiça determinou a realização de processo seletivo para os Colégios Militares (COSTA, 2020). Todavia, a decisão foi reformada pelo Tribunal de Justiça do Tocantins (TOCANTINS, 2020c).

A escola deve cumprir o princípio da gestão democrática, de modo a perseguir um ambiente que valoriza a participaçáo de diferentes atores - trabalhadores, gestores, estudantes e familiares - nas definiçóes do Projeto Político Pedagógico. Os limites do que é ou não admitido na prática escolar devem ser definidos de forma plural pela comunidade escolar (XIMENES, STUCHI e MOREIRA, 2019, p. 619). A Constituição Federal de 1988, a LDB e o ECA preveem a gestão democrática do ensino (item 1.1).

Não se pode afrontar a gestáo escolar democrática, nem mesmo sob o pretexto de tornar as escolas mais democráticas. Apesar de o esforço promovido pela SEDUC em tornar as escolas militarizadas mais próximas do esperado pelo ordenamento jurídico brasileiro - ainda que com pequenas ações, diante da vastidáo de inconsistências -, houve arbitrariedade.

O Manual do Aluno (2014), disponível no sítio oficial da Polícia Militar do Tocantins, tem como finalidade proporcionar ao estudante uma rápida ambientação ao colégio (TOCANTINS, 2014). Conforme esclareceu a SEDUC, via correio eletrônico, o Manual do Aluno publicado em 2014 ainda está vigente.

No capítulo referente à proposta pedagógica, há previsão de que a ação educacional dos colégios militares é conduzida pelos valores, costumes e tradições da PM-TO e tem como metas gerais os princípios estabelecidos em legislação pertinente e no regimento interno. Prevê, também, que a matrícula do aluno significa aceitação incondicional das propostas pedagógicas e disciplinares.

A apresentação individual dos alunos recebe grande destaque no documento, sendo justificada, em caixa alta: 
É IMPORTANTE QUE O ALUNO E SUA FAMÍLIA ENTENDAM QUE O ALUNO UNIFORMIZADO LEVA CONSIGO, O NOME DE UM COLÉGIO DIFERENCIADO DOS DEMAIS, REFERÊNCIA EM EDUCAÇÃO NO ESTADO, DEVENDO REPRESENTÁ-LO À ALTURA DE SUAS TRADIÇÓES.

As tradiçôes e simbolismos militares são responsáveis por boa parte das exigências no que se refere à apresentaçáo pessoal e ao uniforme dos alunos, sendo uma orientação fundamental, inclusive, que os uniformes sejam passados e vincados. Aqueles cujos uniformes estiverem incompletos, sujos, descosturados ou amarrotados podem sofrer punição disciplinar.

Há, também, uma série de regras para a aparência pessoal dos alunos, referentes ao corte e à apresentaçáo do cabelo - que deve ter corte padronizado, proibição do uso de piercings ou alargador na orelha, especificaçóes minuciosas sobre o tipo de maquiagem, anel e brinco permitidos às alunas, dentre outras.

A Recomendação no 04/2019/PRDC/BA/MPF, referente às escolas militarizadas municipais da Bahia, tratou de uma série de determinaçôes feitas aos alunos pelos colégios, inclusive quanto à apresentação pessoal:

CONSIDERANDO que a apresentação pessoal escolhida pelo indivíduo em sua forma de vestir, adereços, corte, penteado e coloraçáo do cabelo, maquiagem, tatuagens, brincos e piercings, é manifestação de sua personalidade, devendo ser respeitada pelo Estado, por força do princípio da dignidade da pessoa humana e da inviolabilidade da intimidade e da vida privada;

CONSIDERANDO, neste sentido, que o Supremo Tribunal Federal, ao julgar inconstitucional a exclusão de candidatos a cargos públicos em razão de tatuagens, reconheceu que "configuram instrumentos de exteriorização da liberdade de manifestação do pensamento e de expressão, valores amplamente tutelados pelo ordenamento jurídico brasileiro (CRFB/88, artigo $5^{\circ}$, IV e IX)", além de reconhecer o "direito fundamental do cidadão preservar sua imagem como reflexo de sua identidade", de modo que o Estado "não pode desempenhar o papel de adversário da liberdade de expressão, incumbindo-lhe, ao revés, assegurar que minorias possam se manifestar livremente" (RE 898450, Tribunal Pleno, julgado em 17/08/2016);

Nesse sentido, a Procuradoria Regional dos Direitos do Cidadáo na Bahia recomendou que as escolas se abstenham de violar ou restringir a liberdade de expressão, intimidade e vida privada de alunos por meio da imposição de padrão estético e que não os fiscalizem e punam em razão de apresentaçáo pessoal, além de não realizar fiscalização e punição de qualquer tipo baseadas unicamente em moralismo, incompatível com o Estado Democrático de Direito.

As regras referentes à aparência dos alunos não têm nenhuma relação com a melhoria do desempenho escolar e violam, ainda, direitos fundamentais.

Há uma estreita correspondência entre os trechos retirados da Recomendação e alguns dispositivos do Guia do Aluno do Colégio Militar. Entende-se, desse modo, que os colégios tocantinenses também devem abster-se de aplicar quaisquer regras 
baseadas unicamente no moralismo e no militarismo, notadamente as que violarem direitos fundamentais.

No Tocantins, o projeto de militarização escolar encontra resistência por parte do Sindicato dos Trabalhadores em Educaçáo no Estado do Tocantins (SINTET). O sindicato publicou, em seu sítio oficial, uma nota em que mostra ser sistematicamente contra o projeto de militarização das escolas, por considerar um retrocesso e ataque à educaçáo pública, bem como uma ofensa à democracia, tendo em vista o método de seleção (ainda aplicado à época da nota) e a exclusão de estudantes economicamente vulneráveis - que não conseguem arcar com os custos dos caros uniformes exigidos (SINTET, 2019?).

Sobre os uniformes, o Manual do aluno (2014) aponta que o Colégio da Polícia Militar não tem convênio com loja que venda uniforme, devendo os responsáveis estarem atentos à aquisição das roupas previstas no manual. $\mathrm{O}$ aluno deve possuir modelos de uniforme escolar para diferentes ocasiôes, como educação física e solenidades.

Em esclarecimento prestado pela SEDUC, via correio eletrônico, afirmou-se que os pais têm liberdade de adquirir o uniforme com a empresa de sua preferência. Ressaltou-se, também, que nenhum aluno é impedido de frequentar às aulas em virtude da falta de uniforme, bem como que a comunidade escolar se mobiliza para disponibilizar uniforme àqueles que não puderem comprar.

O SINTET também manifestou, na mesma nota, que a militarização não combate a violência, e que o modelo escolar aloca militares em escolas sendo que o efetivo de policiais nas ruas é menor do que o necessário (SINTET, 2019). Ao alocar policiais em escolas, torna-se mais precário o policiamento nas ruas, soando contraditório o combate à violência - que frequentemente é justificativa para o modelo.

Em relação à hierarquia adotada pelo modelo militarizado, o Manual do Aluno prevê um sistema em que os próprios alunos se fiscalizam entre si:

No Colégio da Polícia Militar as turmas são dividas de forma hierárquica cabendo às turmas mais antigas a tarefa de orientar e fiscalizar as turmas mais modernas.

O papel de fiscalização disciplinar deixa de ser responsabilidade exclusiva dos servidores que atuam nas escolas e passa a ser uma tarefa dividida com os próprios alunos. Há, também, a figura do aluno fiscal, que conta com curso de formaçáo próprio para exercer tal encargo.

Face ao exposto, os colégios são fortemente norteados por regras militares. Nesse sentido,

Embora a escola e os quartéis se constituam como instituições totalmente diversas, em se tratando das escolas sob a gestão da Polícia Militar é difícil encontrar diferenças entre a burocracia que se instaura nas instituiçóes de ensino e aquela que atua nos quartéis. (PINHEIRO e LUCENA, 2014, p. 546) 
Tem-se, pois, um ambiente escolar cujas regras parecem ter sido transplantadas do quartel. Tais regras, como visto no item 1.2, são questionáveis mesmo no âmbito da formação de militares de carreira. Não há sentido em aplicá-las às escolas de formação educacional civil, em que não se pretende, em tese, capacitar soldados.

\section{CONSIDERAÇÓES FINAIS}

A gestão militarizada de estabelecimentos escolares civis ocorre em um contexto no qual a escola pública é vista como fracassada e o anseio por disciplina clama por um ato de heroísmo de agentes externos à escola - os militares. No Tocantins, a primeira escola estadual militarizada surgiu em 2009, em parceria com a PM-TO e com o nome de Colégio Militar de Palmas. Desde então, o modelo tem se expandido no Estado, que atualmente conta com quinze unidades estaduais.

Apesar de não serem objeto deste trabalho, faz-se relevante ressaltar que há, em Palmas, escolas públicas municipais que passaram por processos semelhantes, mas em parceria com outros órgãos militares (como o Exército Brasileiro e a Marinha do Brasil). Nota-se, pois, que a militarização também ocorre por iniciativas municipais e relacionadas com organismos militares diversos.

A pergunta proposta foi: as estruturas normativas e administrativas das escolas militarizadas do Tocantins atendem os princípios constitucionais e legais da educação básica, na qual se inserem? A análise permitiu observar que algumas disposiçôes vão de encontro a princípios da Educação. O processo seletivo - que, apesar de extinto em 2020, vigorou por alguns anos - não é compatível com o princípio da igualdade de condições para o acesso e permanência na escola (artigo 206, I, CF/1988). A aquisição dos diversos modelos de uniforme escolar também pode constituir um entrave para alguns estudantes, chocando-se tanto com o já mencionado princípio da igualdade de acesso e permanência na escola como com o da gratuidade do ensino (artigo 206, IV, CF/1988). Pode-se falar, também, em desrespeito à gestão democrática (artigo 206, VI, CF/1988) em virtude das mudanças arbitrárias promovidas pela SEDUC - abordadas no capítulo 3.

Exige-se um forte rigor no que diz respeito à apresentaçáo pessoal dos estudantes, bem próximo do exigido em quartéis, como a imposição de cortes de cabelo padronizados e a exigência de que os uniformes sejam passados e vincados. Tais imposiçóes, como visto, podem violar ou restringir a liberdade de expressão, intimidade e vida privada dos alunos.

Ademais, foi possível observar a partir das normativas e documentos que a SEDUC fornece a estrutura escolar (com todos os recursos financeiros que a sustentam) e recursos humanos para atuarem na docência e demais setores e delega as funçóes de gestão pedagógica, administrativa e financeira à PM-TO, que nomeia militares para ocupação dos cargos de coordenação e direção.

Entende-se que a estrutura das escolas militarizadas tocantinenses é protagonizada pela PM-TO, embora sejam instituições de formação civil. Tal ideia apoia-se não somente nos documentos que delegam boa parte das funçóes 
escolares e que destinam os cargos de direção e coordenaçãa a servidores militares, como também no nome adotado pelas instituiçôes, "Colégio Militar do Estado do Tocantins", no padrão de vestimenta dos uniformes escolares, das rígidas diretrizes em relação à aparência dos estudantes, na disciplina baseada no militarismo e em tantos outros símbolos carregados pelas escolas. A Lei Complementar no 79/2012 dispóe, inclusive, que os colégios são órgáos especiais da $\mathrm{PM}-\mathrm{TO}$ - apesar de terem sido criados na estrutura organizacional da SEDUC.

Fica claro, também, que os princípios do Direito Educacional não são integralmente observados e que as normativas para condutas de estudantes são potencialmente violadoras de direitos fundamentais.

A presente análise busca contribuir com a elucidação sobre o surgimento e a expansão de escolas militarizadas no Brasil e no Tocantins, com o esclarecimento sobre como os servidores militares se inserem na estrutura das escolas tocantinenses e com a análise de documentos e normativas referentes a essas instituiçóes, contrastando-os com diplomas legais - notadamente no que diz respeito à educação.

Encontra, também, lacunas possíveis de estudo em trabalhos vindouros: poderia uma escola pertencente à estrutura da SEDUC - e por esta mantida - ser incorporada à da PM-TO, por força de Lei Complementar? Acredita-se que um estudo mais aprofundado do processo administrativo de implantação dessas escolas, compreendendo todos documentos, justificativas formais, atos administrativos e leis que o embasa seja de grande contribuiçáo para o melhor entendimento do fenômeno da militarização das escolas no Tocantins.

\section{REFERÊNCIAS}

AF Notícias. Seduc fará consulta pública sobre mudança de nome dos colégios militares do Tocantins, diz MPTO. AF Notícias, 2019. Disponível em: https:// afnoticias.com.br/estado/seduc-fara-consulta-publica-sobre-mudanca-de-nome-doscolegios-militares-do-tocantins-diz-mpto. Acesso em: 18 fev. 2020.

\section{BRASIL. [Constituição (1988)]. Constituição da República Federativa do Brasil} de 1988. Brasília, DF: Presidência da República, [2019]. Disponível em: http://www. planalto.gov.br/ccivil_03/constituicao/constituicao.htm. Acesso em: 20 fev. 2020.

. Ministério da Educação e Cultura. Lei n. 9.394, de 20 de dezembro de 1996, Lei de Diretrizes e Bases da Educação Nacional. Brasília: MEC/SEF, 1996.

Lei no 8.069, de 13 de julho de 1990. Dispóe sobre o Estatuto da Criança e do Adolescente e dá outras providências. Diário Oficial [da] República Federativa do Brasil, Brasília, DF, 16 jul. 1990. Disponível em: <http://www.planalto.gov.br/ccivil_03/LEIS/ L8069.htm\#art266>. Acesso em: 02 mar. 2020.

Programa Atletas de Alto Rendimento. [S. 1.]: Ministério da Defesa, [2019?].

Disponível em: https://www.defesa.gov.br/esporte/projeto-atleta-de-alto-rendimento. Acesso em: 15 jun. 2020. 
Sistema Colégio Militar do Brasil. [S.1.]: Ministério da Defesa, [2019?].

Disponível em: http://www.depa.eb.mil.br/sistema-colegio-militar-do-brasil. Acesso em: 20 mar. 2020.

. Exército Brasileiro. 2008. Portaria no 042, de 6 de fevereiro de 2008., [S. 1.], 6 fev. 2008. Disponível em: http://www.cmsm.eb.mil.br/phocadownload/legislacao/ regulamentos/03_Portaria_042_R69-2008.pdf. Acesso em: 12 mar. 2020.

. Projeto Político Pedagógico: Sistema de Colégio Militar do Brasil. Diretoria de Educação Preparatória e Assistencial. 2015.

O que é o programa nacional das escolas cívico-militares? [S.l.]: Ministério da Educação, 2019. Disponível em: http://escolacivicomilitar.mec.gov.br/18-o-programa. Acesso em: 10 nov. 2020.

. Decreto no 10.004, de 5 de setembro de 2019. Institui o Programa Nacional das Escolas Cívico-Militares.

. Grupo de Modelagem para Estudos da Biodiversidade. Instituto Nacional de Pesquisas Espaciais, 2013. Disponível em: http://www.dpi.inpe.br/Ambdata/unidades_ administrativas.php. Acesso em: 18 mar. 2020.

Saiba quais são as $\mathbf{5 4}$ escolas que receberão o modelo cívico-militar do MEC. [S.l.]: Ministério da Educação, 2020. Disponível em: http://escolacivicomilitar.mec.gov. $\mathrm{br} /$ noticias-lista/72-saiba-quais-sao-as-54-escolas-que-receberao-o-modelo-civico-militardo-mec. Acesso em: 03 mar. 2020.

Escola de tempo integral divulga valores do Exército. [S.1.]: Ministério da Defesa, 2017. Disponível em: http://www.eb.mil.br/web/noticias/noticiario-do-exercito// asset_publisher/MjaG93KcunQI/content/22-bi-escola-de-tempo-integral-divulga-valoresdo-exercito. Acesso em: 02 de jul. de 2020.

Comando do $7^{\circ}$ Distrito Naval participa da celebraçáo do aniversário da Escola Almirante Tamandaré. [S.1.]: Ministério da Defesa, 2019. Disponível em: https:// www.marinha.mil.br/noticias/comando-do-7o-distrito-naval-participa-da-celebracao-doaniversario-da-escola-almirante. Acesso em: 02 jul. 2020.

. Recomendação no 04/2019/PRDC/BA/MPF. Bahia: Ministério Público Federal, 2019. Disponível em: http://pfdc.pgr.mpf.mp.br/atuacao-e-conteudos-de-apoio/ recomendacoes/recomendacao-04-2019-prdc-ba-mpf. Acesso em: 28 out. 2019.

BENEVIDES, Alesandra de Araújo; SOARES, Ricardo Brito. Diferencial de desempenho das escolas militares: bons alunos ou boa escola? [S.1.], [201-]. Disponível em: https://www.bnb.gov.br/documents/160445/960917/DIFERENCIAL_DE_ DESEMPENHO_DAS_ESCOLAS_MILITARES.pdf/7ae9ef81-9687-46cb-b501766ccef1cba2. Acesso em: 17 fev. 2020. 
BULOS, Uadi Lâmmego. Curso de Direito Constitucional. 9 ed. [S.l.]: Editora Saraiva, 2015.

Costa, Lailton. Justiça obriga SEDUC a abrir concurso para selecionar alunos para colégios militares. Jornal do Tocantins, 2020. Disponível em: https://www. jornaldotocantins.com.br/editorias/politica/antena-ligada-1.1694939/justi\%C3\%A7aobriga-seduc-a-abrir-concurso-para-selecionar-alunos-para-col\%C3\%A9giosmilitares-1.1983203. Acesso em: 18 fev. 2020

CURY, Carlos Roberto Jamil. A educaçáo básica como direito. Cad. Pesqui. [online]. 2008, vol.38, n.134, pp.293-303. ISSN 1980-5314. https://doi.org/10.1590/S010015742008000200002.

DE ARAÚJO, Gilda Cardoso. Direito à educação básica: a cooperação entre os entes federados. Revista Retratos da Escola, Brasília, v. 4, n. 7, p. 231-243, jul./dez. 2010.

Federalismo cooperativo e educaçáo no Brasil: 30 anos de omissóes e ambivalências. Educ. Soc., Campinas, v. 39, no. 145, p.908-927, out.-dez., 2018.

DI PIETRO, Maria Sylvia Zanella. Direito Administrativo. São Paulo: Editora Atlas S.A., 2014.

Educa Mais Brasil. Escola Estadual Hercília Carvalho da Silva. 2020. Disponível em: https://www.educamaisbrasil.com.br/escolas/escola-estadual-hercilia-carvalho-da-silva. Acesso em: 02 dez. 2020.

Educa Mais Brasil. Escola Estadual Maria dos Reis Alves Barros. 2020. Disponível em: https://www.educamaisbrasil.com.br/escolas/escola-estadual-maria-dos-reis-alves-barros. Acesso em: 02 dez. 2020.

Educa Mais Brasil. Escola Estadual São José Operário. 2020. Disponível em: https:// www.educamaisbrasil.com.br/escolas/escola-estadual-sao-jose-operario-paraiso-dotocantins-to. Acesso em: $02 \mathrm{dez} .2020$.

GUIMARÁES, P. C. P. Os novos modelos de gestão militarizadas das escolas estaduais de Goiás. XXIX Simpósio Nacional de História. Contra os preconceitos: História e Democracia. 2017. Disponível em: http://www.snh2017.anpuh.org/resources/ anais/54/1502846486_ARQUIVO_TRABALHO_COMPLETO_ANPUH_Paula_2017(1).pdf. Acesso em: 28 out 2019.

LEAL, Saul Tourinho. Obstáculos Constitucionais à militarizaçáo das escolas públicas. Migalhas, [S.1.]: Migalhas, 2017. Disponível em: https://www.migalhas.com.br/Conversa Constitucional/113,MI264512,81042-Obstaculos+constitucionais+a+militarizacao+das+e scolas+publicas. Acesso em: 28 de out. 2019.

LIMA, I. F. F.; OLIVEIRA, I. M. Segurança Pública Militarizada: a face antidemocrática do Estado de Direito. Aracaju: Interfaces Científicas - Direito. v. 4, n. 2, p. 93-102, 2016. 
MATUOKA, I. As diferenças entre escola militar, cívico-militar e pública. [S.1.]: Centro de Referências em Educação Integral, 2019. Disponível em: https:// educacaointegral.org.br/reportagens/as-diferencas-entre-escola-militar-civico-militar-epublica/. Acesso em: 27 out. 2019.

MOREIRA, A; SALLES, L. M. F. O ECA e a concretização do direito à educação básica. R. Educ. Públ. Cuiabá, v. 24, n. 55, p. 177-198, jan./abr. 2015.

MELLO, Celso Antônio Bandeira de. Curso de Direito Administrativo. [S.1.]: Malheiros Editores, 2012.

PINHEIRO, V.; LUCENA, C. A. As escolas públicas de educação básica do estado de Goiás e a gestão da Polícia Militar. IN: ANAIS DA XII JORNADA DO HISTEDBR e X SEMINÁRIO DE DEZEMBRO. 2014. p. 543 - 556.

RANIERI, Nina Beatriz Stocco. O direito educacional no sistema jurídico brasileiro. In: Justiça pela qualidade da educação [S.I: s.n.], 2013.

SINTET. Nota do Sintet sobre a militarização das escolas públicas no Tocantins. Sintet, 2019? Disponível em: http://www.sintet.org.br/ultimasnoticias-708-nota-dosintet-sobre-a-militarizacao-das-escolas-publicas-no-tocantins. Acesso em: 02 jul. 2020.

ROCHA, J. D. T.; SILVA FILHO, T. M.; SANTOS, J. S. Educaçáo prussiana liberal: a gênese histórica do modelo militarista de educaçáo no Tocantins. ESCRITAS Vol. 9 n. 1 (2017) ISSN 2238-7188 p. 7-21.

TEIXEIRA, Anísio. Autonomia para a Educação. In: ROCHA, João Augusto de Lima (Org.). Anísio em movimento. Brasília: Senado Federal/Conselho Editorial, 2002.

TOCANTINS. Proerd - Programa Educacional de Resistência às Drogas e à Violência. [S.1.]: Polícia Militar, [201-?]. Disponível em: https://www.pm.to.gov.br/ institucional/estrutura-geral/04-rgaos-especiais/proerd---programa-educacional-deresistencia-as-drogas-e-a-violencia/02-o-que-e-o-proerd/. Acesso em: 30 jun. 2020.

Colégio Militar do estado do Tocantins. [S.1.]: Polícia Militar, 2020.

Disponível em: https://www.pm.to.gov.br/04-rgaos-especiais/colegio--militar-do-estadodo-tocantins/perfil-historico/. Acesso em: 02 mar. 2020.

. Colégio Militar do estado do Tocantins. [S.1.]: Polícia Militar, 2020.

Disponível em: https://www.pm.to.gov.br/04-rgaos-especiais/colegio--militar-do-estadodo-tocantins/. Acesso em: 02 dez. 2020.

. Em Palmeirópolis, governador Carlesse lança Colégio Militar e garante implantaçáo de mais 33 unidades no Tocantins. [S.1.]: Portal Tocantins, 2019. Disponível em: https://portal.to.gov.br/noticia/2019/9/9/em-palmeiropolis governadorcarlesse-lanca-colegio-militar-e-garante-implantacao-de-mais-33 unidades-no-tocantins/. Acesso em: 20 fev. 2020. 
. Lei Complementar no 79, de 27 de abril de 2012. Palmas: Assembleia

Legislativa do Estado do Tocantins, 2012.

. Lei Complementar no 83 de 04 de setembro de 2012. Palmas: Assembleia Legislativa do Estado do Tocantins, 2012.

Decreto no 5.819 de maio de 2018. Palmas: Assembleia Legislativa do Estado do Tocantins, 2012.

. Secretaria de Estado da Educação, Juventude e Esportes. Termo de Parceria no 11/2019, de 25 de junho de 2019. Diário Oficial do Estado [do] Estado do Tocantins: Poder Executivo, Palmas, ano 31, n. 5387, p. 9, 28 jun. 2019.

. Secretaria de Estado da Educação, Juventude e Esportes. Termo de Cooperação Técnica no 008/2015, de 28 de outubro de 2015. Diário Oficial do Estado [do] Estado do Tocantins: Poder Executivo, Palmas, ano 27, n. 4493, p. 22, 9 nov. 2015.

. Secretaria de Estado da Educação, Juventude e Esportes. Termo de Cooperaçáo Técnica no 017/2018, de dezembro de 2018.

. Entenda o novo formato de ingresso nos colégios cívico-militares no Tocantins. [S.1.]: Portal Tocantins, 2019. Disponível em: https://portal.to.gov.br/ noticia/2019/10/31/entenda-o-novo-formato-de-ingresso-nos-colegios-civico-militaresno-tocantins/. Acesso em: 18 fev. 2020.

. Deputado questiona fim do processo seletivo em colégios militares. Assembleia Legislativa do Tocantins, 2019. Disponível em: https:/www.al.to.leg.br/noticia/gabinete/ professor-junior-geo/8340/deputado-questiona-fim-do-processo-seletivo-em-colegiosmilitares. Acesso em: 18 fev. 2020.

. CPM, Colégio da Polícia Militar. Manual do Aluno. [S.1.], 2014. Disponível em: https://www.pm.to.gov.br/noticia/2014/1/9/colegio-da-policia-militar-publicamanual-do-aluno/. Acesso em: 27 nov. 2020.

. Tribunal de Justiça derruba liminar que determinava a realizaçáo de processo seletivo para colégios militares. Portal do Tocantins, 2020. Disponível em: https:// portal.to.gov.br/noticia/2020/2/3/tribunal-de-justica-derruba-liminar-que-determinavarealizacao-de-processo-seletivo-para-colegios-militares/. Acesso em: 18 fev. 2020.

VEIGA, C. C. P. S.; SOUZA, J. S. Pedagogia Militar: do conceito a sua aplicação. Rev. HISTEDBR On-line Campinas, SP v.19 1-22 e019045 2019.

ZAVERUCHA, J. Relaçóes civil-militares: o legado autoritário da constituição brasileira de 1988. In E. Teles \&Safatle (Orgs.). O que resta da ditadura: a exceção brasileira (pp. 41-76). São Paulo: Boitempo, 2010. 